\title{
Analysis of total calorie, calcium and protein intake and relationship with bone mineral density in postmenopausal women
}

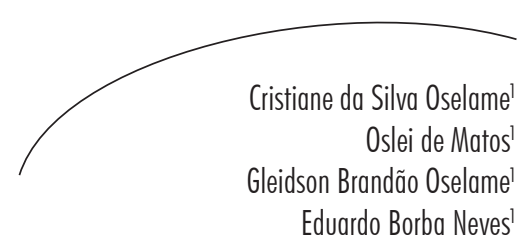

Abstract

Introduction: the adequate intake of nutrients involved in bone metabolism can prevent and even reduce the risk of osteoporosis. Objective: verify the intake of total calories, protein and calcium in women diagnosed with osteopenia and osteoporosis after menopause. Method: a study of 25 women diagnosed with osteopenia $(n=17)$ or osteoporosis $(n=8)$ in the postmenopausal period, who were members of the Prática de Exercícios Físicos na Osteoporose (Practice of Physical Exercise Against Osteoporosis) (PEFO) study group of the Universidade Tecnológica Federal do Paraná (the Federal Technology University of Paraná) (UTFPR). The study was divided into two data collection phases: assessment of body composition and bone mineral density by Dual-energy X-ray Absorptiometry (DXA) and the recording of food consumption over the previous 72 hours by means of a structured interview. Results: there was a difference between the reference values and

Keywords: Osteoporosis, the average values found for caloric, protein and calcium intake. There were higher values for protein, while calcium intake was low. The osteoporosis group (mean 59.24+80.07, $p<0.05$ ) ingested significantly more protein than the osteopenia group (mean 15.14+16.53, $p<0.05)$. The results showed a significant negative correlation between protein intake and hip BMD ( $\mathrm{r}=-0.416, p<0.05)$. Conclusion: adequate intake of protein should be recognized as a protective factor for osteoporosis and considered by nutritionists, as well as being widely featured in public health campaigns.

Universidade Tecnológica Federal do Paraná, Programa de Pós Graduação em Engenharia Biomédica. Curitiba, PR, Brasil.

Correspondence

Gleidson Brandão Oselame

Email: gleidsonoselame@gmail.com 


\section{INTRODUCTION}

The increase in chronic diseases such as osteoporosis is a major consequence of the phenomenon of population aging and is currently regarded as a serious public health problem. ${ }^{1}$

Osteoporosis is understood to be a skeletal disorder associated with decreased mass and the deterioration of bone microarchitecture, leading to an increased risk of fractures. ${ }^{2}$ It is estimated that osteoporosis affects over 75 million people worldwide. ${ }^{1}$

It is believed that osteoporosis affects $35 \%$ to $52 \%$ of women aged over fifty and that twenty per cent of women are affected by the condition. This high prevalence means that more than $\$ 1$ billion is spent on treatment per year. ${ }^{1}$

The risk factors for osteoporosis include lifestyle; endocrine status; genetic factors; surgery; medicines and dietary habits. ${ }^{3}$ Estrogen deficiency is acknowledged as being directly related to menopause, characterized by marked bone loss. ${ }^{3}$

One of the factors that influence the onset of osteoporosis is poor eating habits. The adequate intake of nutrients involved in bone metabolism can prevent and even reduce the risk of the onset of the condition. The intake and absorption of bone building nutrients is required even after the onset of osteoporosis. These nutrients include proteins, minerals (calcium, phosphorus, potassium) and vitamins $(\mathrm{D}, \mathrm{K}, \mathrm{B} 12){ }^{4}$

However, the excessive intake of protein, sodium and vitamin A can promote bone demineralization, making the bone more prone to fracture. ${ }^{4}$ Therefore, proper dietary balance is a major factor in preventing osteoporosis. ${ }^{5}$

The objective of the present study was to assess the intake of total calories, protein and calcium in women diagnosed with osteopenia and osteoporosis after menopause.

\section{METHODS}

We conducted a study of 25 women in the postmenopausal period diagnosed with osteopenia or osteoporosis, who were participants in the Prática de Exercícios Físicos na Osteoporose (Practice of Physical Exercise Against Osteoporosis) (PEFO) study group of the Universidade Tecnológica Federal do Paraná (Federal Technology University of Paraná) (UTFPR), in the city of Curitiba, in the state of Paraná. The selection of participants was performed in an automatic and random manner, comprising women participating in the PEFO group. The inclusion criteria were: suffer from osteopenia and/or osteoporosis confirmed by Dual-energy X-ray Absorptiometry (DXA), and be in the postmenopausal period. Women who could not perform the DXA examination for assessment of bone mineral density for any reason and those who used some sort of measure that could interfere with bone resorption were excluded.

The study was divided into two data collection phases: assessment of body composition and bone mineral density by Dual-energy X-ray Absorptiometry (DXA) and completion of a food consumption record for the previous 72 hours by means of a structured interview. These two phases were carried out on the same day, aiming to facilitate the transport arrangements of participants.

The DXA evaluation was performed with volunteers wearing only clothes of light fabric, barefoot, without any metallic materials. They were made comfortable on the table in a supine position, remaining motionless throughout the complete body measurement. This review was carried out by an experienced professional skilled in the performance of such exams.

To evaluate food consumption recall, analysis of each separate meal was performed (breakfast, morning snack, lunch, afternoon snack, dinner and supper). For the calculation of indicators of 
total calorie intake, carbohydrates (calories and grams), protein (calories and grams), lipids (calories and grams) calcium (mg), zinc (mg), caffeine ( $\mathrm{mg}$ ) sodium ( $\mathrm{mg}$ ) manganese (mg), magnesium ( $\mathrm{mg}$ ), phosphorus (mg), dietary fiber $(\mathrm{g})$, vitamin $\mathrm{d}$ $(\mu \mathrm{g} / \mathrm{d})$, iron $(\mathrm{mg})$ and copper $(\mathrm{mg})$ the Diet Pro

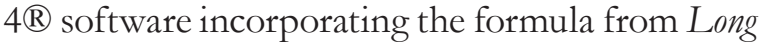
\&Harris-Benedict ${ }^{6}$ (Equation 1) was used.

(1) $\mathrm{BEE}=655+(9.6 \times \mathrm{Wt})+(1.85 \times \mathrm{Ht})-(4.676 \times \mathrm{age})$

$\mathrm{BEE}=$ basal energy expenditure; $\mathrm{Wt}=$ current weight in $\mathrm{kg}$; $\mathrm{Ht}=$ height in $\mathrm{cm}$; age $=$ age in years

In cases where the food described by the interviewee was not found in the software database, the Tabela Brasileira de Composição de Alimentos (Brazilian Food Composition Table) (TACO) as a reference. The Dietary Reference Intake by age (women aged 50 or more) table was also used. The record was created by a professional nutritionist.

The measurement of the weight of the participants was performed using a Geratherm brand digital scale with a maximum capacity of 150 $\mathrm{kg}$ and a range of $100 \mathrm{~g}$. Height was measured with a Wiso stadiometer with precision in $\mathrm{mm}$, fixed to a wall with no baseboard, with an extension of two meters.

Data collection was performed in the first quarter of 2014 in the Biochemistry and Densitometry Research Laboratory (LABDEN) of UTFPR in a designated room to ensure the privacy of the women during all processes. The evaluations were scheduled with the women seven (7) days in advance and confirmed by phone 24 hours prior to the assessment.

The data was analyzed according to the following parameters: ideal calorie consumption estimated by the Long \& Harris-Benedict formula (Equation 1); individual protein requirement, using the reference of the National Research Council ${ }^{7}$ which suggests a $0.8 \mathrm{~g} / \mathrm{kg}$ (protein/weight) ratio; individual calcium requirement, using Dietary Reference Intakes (DRI), which suggests that those aged over 50 should have at least 1,200 mg of calcium per day; and classification of bone mineral density values, based on the parameters of the World Health Organization, which considers osteopenia to be $\mathrm{BMD}$ results in the range between populational mean -1.1 standard deviations and populational mean -2.49 standard deviations, and osteoporosis mineral bone densities lower than the populational mean -2.5 standard deviations.

As this study involved human beings, the guidelines of National Health Council resolution 466 dated December 12, 2012, were followed. All the participants were fully informed about the objectives of the study, and their participation was voluntary and did not involve onuses or bonuses. All the participants signed a free and informed consent form. The study was approved under Opinion No. CAAE: 21751513.0.0000.5547 on February 13, 2014 by the Research Ethics Committee of the Federal Technology University of Paraná.

The data was evaluated using descriptive and analytical statistical analysis using the Statistical Package for the Social Sciences (SPSS) software package, considering a level of significance of $p<0.05$. To analyze the differences between the two groups of the sample (osteopenia/osteoporosis) the Wilcoxon-Mann-Whitney Test for independent samples was used.

\section{RESULTS}

25 volunteers were evaluated, of which 17 had osteopenia and eight had osteoporosis. Table 1 shows the profile of the study sample. 
Table 1. Characterization of 25 women diagnosed with osteopenia or osteoporosis in the post-menopause period, who were participants of the Practice of Physical Exercise Against Osteoporosis (PEFO) study group of the Universidade Tecnológica Federal do Paraná (the Federal Technology University of Paraná) (UTFPR). Curitiba, Paraná, 2014.

\begin{tabular}{|c|c|c|c|c|c|c|}
\hline Variable & Group & $\mathrm{n}$ & Minimum & Maximum & Mean & $\begin{array}{l}\text { Standard } \\
\text { deviation }\end{array}$ \\
\hline \multirow[t]{2}{*}{ Age } & Osteopenia & 17 & 46.00 & 68.00 & 58.24 & 6.08 \\
\hline & Osteoporosis & 8 & 48.00 & 73.00 & 62.38 & 7.91 \\
\hline \multirow[t]{2}{*}{ Height } & Osteopenia & 17 & 1.43 & 1.68 & 1.57 & 0.07 \\
\hline & Osteoporosis & 8 & 1.48 & 1.64 & 1.56 & 0.07 \\
\hline \multirow[t]{2}{*}{ Weight } & Osteopenia & 17 & 45.50 & 103.30 & 67.08 & 14.34 \\
\hline & Osteoporosis & 8 & 49.50 & 80.50 & 64.15 & 8.82 \\
\hline \multirow{2}{*}{ Waist circumference } & Osteopenia & 17 & 65.00 & 131.00 & 89.00 & 15.80 \\
\hline & Osteoporosis & 8 & 75.00 & 103.00 & 89.75 & 9.62 \\
\hline \multirow{2}{*}{ Hip circumference } & Osteopenia & 17 & 79.00 & 127.00 & 99.53 & 11.42 \\
\hline & Osteoporosis & 8 & 90.00 & 105.00 & 96.75 & 6.04 \\
\hline \multirow{2}{*}{ Waist-Hip Ratio } & Osteopenia & 17 & 0.71 & 1.03 & 0.85 & 0.09 \\
\hline & Osteoporosis & 8 & 0.82 & 1.01 & 0.89 & 0.07 \\
\hline \multirow{2}{*}{$\begin{array}{l}\text { Difference in Kcal intake } \\
\text { (Referred - Ideal) }\end{array}$} & Osteopenia & 17 & -463.82 & 885.46 & 191.92 & 443.95 \\
\hline & Osteoporosis & 8 & -318.41 & 1109.07 & 406.58 & 480.52 \\
\hline \multirow{2}{*}{$\begin{array}{l}\text { Difference in Protein Intake* } \\
\text { (Referred - Ideal) }\end{array}$} & Osteopenia & 17 & -16.50 & 48.69 & 15.14 & 16.53 \\
\hline & Osteoporosis & 8 & -10.35 & 250.04 & 59.24 & 80.07 \\
\hline \multirow{2}{*}{$\begin{array}{l}\text { Difference in Calcium Intake } \\
\text { (Referred - Ideal) }\end{array}$} & Osteopenia & 17 & -1178.40 & 128.54 & -805.05 & 363.02 \\
\hline & Osteoporosis & 8 & -1119.30 & 1.05 & -611.35 & 407.64 \\
\hline
\end{tabular}

* Variable representing significant statistical difference between osteoporosis and osteopenia groups in the Wilcoxon-Mann-Whitney Test ( $\mathrm{p}=0.023$ ). Kcal=kilocalories

Differences were observed between the reference values and the measured caloric intake, protein intake and calcium values. The most significant values were the high protein and the low calcium intake. Both groups had high Waist-Hip Ratio (WHR) values. It was observed that the osteoporosis group ingested significantly more protein $(p=0.023)$ than the osteopenia group. There were no significant differences between the groups for the variables total caloric intake and calcium intake, however.
The Kolmogorov-Smirnov test was used for sample distribution analysis, and determined that the variables "difference between protein intake" and "protein consumption difference" did not approach Gaussian distribution. Considering the size of the study groups, it was decided to use non-parametric statistics for data analysis. Table 2 shows these variables. 
Table 2. Spearman correlation between intake variables and BMD of 25 women diagnosed with osteopenia or osteoporosis in the post-menopausal period, participants of the Practice of Physical Exercise Against Osteoporosis (PEFO) study group of the Universidade Tecnológica Federal do Paraná (the Federal Technology University of Paraná) (UTFPR). Curitiba, Paraná, 2014.

\begin{tabular}{lccccc}
\hline \multicolumn{1}{c}{ Variables } & $\begin{array}{c}\text { Difference in } \\
\text { kilocalorie } \\
\text { intake }\end{array}$ & $\begin{array}{c}\text { Difference in } \\
\text { protein intake }\end{array}$ & $\begin{array}{c}\text { Difference } \\
\text { in calcium } \\
\text { intake }\end{array}$ & $\begin{array}{c}\text { BMD } \\
\text { Femur }\end{array}$ & $\begin{array}{c}\text { BMD } \\
\text { Spine }\end{array}$ \\
\hline Difference in kilocalorie intake & 1.000 & $0.668^{* *}$ & 0.148 & -0.290 & -0.162 \\
Difference in protein intake & & 1.000 & 0.212 & $-0.416^{*}$ & -0.255 \\
Difference in calcium intake & & & 1.000 & -0.078 & -0.145 \\
BMD Femur & & & & 1.000 & 0.182 \\
BMD Spine & & & & 1.000 \\
\hline
\end{tabular}

* Significant correlation at 0.05 level ( 2 extremities). ** significant correlation at 0.01 level ( 2 extremities).

The Bone Mineral Density (BMD) values were analyzed in absolute terms $\left(\mathrm{g} / \mathrm{cm}^{2}\right)$. The results displayed a negative correlation between the intake of proteins and the BMD of the femur (-0.416).

\section{DISCUSSION}

Osteoporosis is a disease characterized by reduced bone mass and the microarchitectural disruption of the bone. This occurrence leads to an increased risk of fractures. It is closely related to the menopausal and postmenopausal periods. ${ }^{8}$

The physiological process of bone growth remodeling requires the involvement of many nutrients. These include calcium, vitamin D and proteins, as well as other nutrients such as potassium, magnesium and vitamin $\mathrm{K}$, which may also be related to benefits for bone health. ${ }^{?}$

These nutrients initially originate from a suitable food intake. In the women analyzed the parameters relating to food consumption denoted a nutritional imbalance in terms of the actual situation of bone demineralization presented by the sample.

Calcium is the most abundant mineral in the human body, mainly located in the bones and teeth $(99 \%)$. The intake of an appropriate amount of calcium is essential for the maintenance of healthy bones. The calcium intake from the diet is absorbed in the intestinal tract, and is divided into two parts: the active saturable part, mediated by vitamin $\mathrm{D}$ and the calcium-binding protein, and the passive part, through simple or facilitated diffusion. ${ }^{10}$

In this regard, it is noteworthy that the only source of calcium available to the human body comes from the diet. The main dietary source of calcium comes from milk and milk products and dark green leaf vegetables. Data indicates that in Brazil calcium intake is below ideal, with a national average of 300 to $500 \mathrm{mg} /$ day. $^{11}$

The women performed in this study had a high protein and a low calcium intake. Similarly, in the study by Pinheiro et al., ${ }^{12}$ which evaluated 2420 subjects aged over 40 years and sought to evaluate the relationship between nutrient intake and osteoporotic fractures, the authors found that $99 \%$ of this population had a calcium intake below the recommended level (1200 mg/day).

A study by Straub ${ }^{13}$ which evaluated 142 healthy women in the pre-menopausal period, found that the average absorption of calcium was only $35 \%$, ranging from $17 \%$ to $58 \%$. It is also notable that the absorption of calcium was inversely related to the total intake of dietary fiber and calcium. 
A number of factors influence calcium absorption, including: levels of vitamin $\mathrm{D}$, gastric acidity, age, estrogen levels and dietary fiber intake. In case of low levels of vitamin $\mathrm{D}$, it is estimated that only 10 to $15 \%$ of calcium is absorbed. ${ }^{13}$

Another variable analyzed was protein intake. The protein intake observed in women was considerably higher than ideal levels, which can result in losses in bone mineral density. A greater preference among women for protein-rich foods was observed. Thus, attention should be paid to the fact that excessive protein intake can lead to increased loss of calcium, especially through increased renal excretion, and consequently damage the bone health of these women. ${ }^{14-15}$

The consumption of hyperprotein diets can lead to metabolic acidosis, promoting bone resorption and inhibiting the action of osteoblasts, thus damaging bone structure. On this basis, Silva et al., ${ }^{16}$ proposed to evaluate possible changes in the bone tissue of Wistar rats when fed with a so-called "protein diet". They concluded that this type of diet (high-protein) caused changes in bone remodeling, presumably due to decreased bone formation activity and greater demineralization. It is therefore suggested that adult women in the pre-menopausal and menopausal periods tend to develop osteopenia and osteoporosis due to a high protein intake. $^{16}$

However, calcium and protein, are primarily responsible for bone tissue construction. There are therefore positive and negative effects of protein intake. These positive effects are more common in older people with a high intake of calcium rich foods than people with lower consumption. ${ }^{17}$ This reality was not found in the group of women studied, as the calcium intake was below ideal levels.

A study by Zhong et al., ${ }^{18}$ investigated the association between calcium and protein intake and the risk of fractures. More than two thousand women in the post-menopausal period evaluated in the National Health and Nutrition Examination Survey 1999-2002 took part in the study. The results showed that women with a total calcium intake $\geq 1200 \mathrm{mg} /$ day and a protein consumption $<46 \mathrm{~g} /$ day were at a greater risk of fractures than those with a lower calcium intake. The ratio between calcium and protein intake should be investigated more fully, primarily among older women.

It is estimated that for every $50 \mathrm{~g}$ of protein consumed there is an increase in urinary calcium of $60 \mathrm{mg} /$ day. This is due to the fact that excess dietary protein increases urinary calcium by about $50 \%$. In other words, for every gram of protein metabolized there is an increase in urinary calcium concentration of $1.75 \mathrm{mg}$. It should be noted that the negative effect of protein on bone metabolism is seen only if the calcium intake is below the ideal level. ${ }^{19}$ This finding is in line with the results for the women evaluated in the present study (high protein and low calcium intake). It is estimated that a ratio of calcium to protein greater than 20:1 can protect the bones. ${ }^{19}$

In this context, the inadequate intake of calcium and protein represents a greater risk of the development of osteopenia and osteoporosis. This situation can lead to fractures that are often very serious, depending on anatomical location.

A review by Pinheiro and Eis ${ }^{20}$ found a moderate incidence of hip fractures in subjects aged over 50 , representing between $11 \%$ and $23.8 \%$ of fractures in all anatomical locations. It should be noted that according to Brazilian studies, the mortality rate 12 months after the occurrence of fractures ranged from $21.5 \%$ to $30 \%$. In this sense, it is clear that osteoporosis should be considered a serious public health problem. ${ }^{20}$

It is estimated that there are approximately 9 million fractures caused by osteoporosis worldwide each year. Of these, 1.6 million affect the hip, 1.7 million occur at the distal end of the forearm and 1.4 million are in the vertebrae. It is noteworthy that the risk of women over 50 suffering fractures is $32 \%$ in the vertebral region and $16 \%$ for the distal end of the femur. ${ }^{21}$

Therefore, it is suggested that when there is insufficient calcium intake, high protein intake and osteoporosis/osteopenia identified by DXA analysis, the risk of fractures occurring should be 
considered and, in the first instance, prevented by educational actions and the improvement of food consumption levels.

In terms of the limitations of this study, possible bias related to the recall of food intake should be mentioned, as the method depends on the memory of the participant regarding what was consumed at each meal, as well as the cross-sectional nature of the study, with a limited number of participants with the profile stipulated for analysis.

\section{CONCLUSION}

Bone structure is dependent on complex processes which involve intake, absorption capacity and the need for fixation of the organic

\section{REFERENCES}

1. Dourado CM. Densidade mineral óssea em idosos e presença de fatores de risco nutricionais para osteoporose [Dissertação]. Porto Alegre: Pontifícia Universidade Católica do Rio Grande do Sul; 2012.

2. Carvalho M, Kulak CAM, Borba VZC. Prevalência de hipercalciúria em mulheres na pós-menopausa com osteoporose. Arq Bras Endocrinol Metab 2012;56(1):1-5.

3. Herdina SR. Atividade física e sua implicação sobre a densidade mineral óssea de mulheres na menopausa [Dissertação]. Florianópolis: Universidade Federal de Santa Catarina; 2012.

4. Morais GQ, Burgos MGPA. Nutrients impact on bone health: new trends. Rev Bras Ortop 2007;42(7):189-94.

5. Ripka WL, Matos O. Relação entre índice de massa corporal e densidade mineral óssea em osteoporóticas pós-menopausicas. Rev Uniandrade 2009;10(2):45-51.

6. Harris JA, Benedict FG. A biometric study of basal metabolism in man. Washington: Carnegie Institution of Washington; 1919.

7. National Research Council. Subcomittee on the tenth edition of the RDAs. Recommended dietary alowances. 10th ed. Washington: National Academy Press; 1989.

8. Lanzillotti HS, Lanzillotti RS, Trotte APR, Dias AS, Bornand B, Costa EAMM. Osteoporose em mulheres na pós-menopausa, cálcio dietético e outros fatores de risco. Rev Nutr 2003;16(2):181-93. and inorganic substances involved in constant bone remodeling. Therefore, the lack of nutritional control of the evaluated women is directly linked to their reduced BMD. This factor is explained by their high protein intake and the mineral consumption below reference values, especially in the low BMD group.

Finally, the results suggest that adequate calcium intake alone is not sufficient for the protection of bones. Regular protein intake associated with other protective factors (sun, vitamin $\mathrm{D}$, physical activity) is essential and this information should be disseminated widely to health professionals and via public health campaigns. We recommend further research with larger samples and the daily recording of food intake in order to verify the results found in the present study.

9. Levis S, Lagari VS. The role of diet in osteoporosis prevention and management. Curr Osteoporos Rep 2012;10(4):296-302.

10. Almeida SG, Monte LM, Garcia PPC. Biodisponibilidade de cálcio numa dieta isenta de leite de vaca e derivados. Ensaios Ciênc 2011;15(3):147-58.

11. Cozzolino SMF. Biodisponibilidade de micronutrientes.São Paulo: MANOLE; 2005.

12. Pinheiro MM, Schuch NJ, Genaro PS, Ciconelli RM, Ferraz MB, Martini LA. Nutrient intakes related to osteoporotic fractures in men and women-the Brazilian Osteoporosis Study (BRAZOS). Nutr J 2009;8(6):1-8.

13. Straub DA. Calcium supplementation in clinical practice: a review of forms, doses, and indications. Nutr Clin Pract 2007;22(3):286-96.

14. Montilla RNG, Aldrighi JM, Marucci MFN. Relação cálcio/proteína da dieta de mulheres no climatério. Rev Assoc Med Bras 2004;50(1):52-4.

15. Montilla RN, Marucci MFN, Aldrighi JM. Avaliação do estado nutricional e do consumo alimentar de mulheres no climatério. Rev Assoc Med Bras 2003;49(1):91-5.

16. Silva ZN, Jesuz VA, Castro ES, Boaventura GT, Azeredo VB. Efeito da "dieta da proteína" no tecido ósseo de ratas. Nutrire Rev Soc Bras Aliment Nutr 2013;38(Supl):79. 
17. Coutinho SMB. Avaliação da ingestão alimentar ea suplementação de cálcio em mulheres no climatério e pós-menopausa [Dissertação]. Porto Alegre: Pontifícia Universidade Católica do Rio Grande do Sul; 2013.

18. Zhong Y, Okoro CA, Balluz LS. Association of total calcium and dietary protein intakes with fracture risk in postmenopausal women: The 1999-2002 National Health and Nutrition Examination Survey (NHANES). Nutrition 2009;25(6):647-54
19. Buzinaro EF, Almeida RN, Mazeto GM. Bioavailability of dietary calcium. Arq Bras Endocrinol Metab 2006;50(5):852-61.

20. Pinheiro MM, Eis SR. Epidemiology of osteoporotic fractures in Brazil: what we have and what we need. Arq Bras Endocrinol Metabol 2010;54(2):164-70.

21. Martins GSB, Beal JR, Figueiredo MC, Sampaio PRL, Netto OS. Comparação da densidade mineral óssea de coluna lombar e colo femoral. Rev Med Saúde Brasília 2013;2(1):19-25.

Received: June 08, 2015

Reviewed: January 04, 2016

Accepted: June 20, 2016 